\section{Ornithologists stunned by bird collector's deceit}

\section{SANTA BARBARA}

The British Colonel Richard Meinertzhagen earned many illustrious titles during his life of globe-trotting, including soldier, spy and even scientist. Now an extensive analysis of bird specimens he collected across continents adds another label: fraud artist.

Meinertzhagen, who died in 1967 , donated some 20,000 bird specimens to the British Natural History Museum in Tring in 1954. The museum has one of the world's largest ornithological collections, with around two million items, and is an internationally important archive for biology and ecology studies.

But a large proportion of the specimens Meinertzhagen donated were fraudulently labelled and many were stolen, according to a report presented late last month at the annual meeting of the American Ornithologists' Union in Santa Barbara, California.

Pamela Rasmussen, an ornithologist at Michigan State University in Lansing, and Robert Prys-Jones, head of the collection at Tring, began investigating Meinertzhagen's specimens from Asia after fraudulently labelled finches were reported in 1993. It has taken sophisticated forensic techniques and well over a decade of work to uncover the extent of the deceit. ${ }^{\alpha}$ There are hundreds and probably thousands of fraudulently catalogued specimens," says Rasmussen. "This was going on for the better part of his life."

A member of the Royal Fusiliers, Meinertzhagen served in the Middle East, Africa and across the Asian subcontinent, campaigning with the likes of Lawrence of Arabia. Substantial portions of his collection are thought to be valid and important, including many specimens from Afghanistan. But Rasmussen and Prys-Jones found that, as early as 1914, Meinertzhagen was stealing specimens from the British Museum and other institutions, then retagging them with catalogue details of his own makexample of fraud that I am aware of," says Prys-Jones.

And it may have played havoc with the condusions of biologists who subsequently studied the specimens. Museum collections of bird skins, skeletons, nests and eggs are the primary record by which biologists chart the life of species. Stored items are marked with small tags that contain crucial details of a specimen's life history, such as favoured climate and geographic location.

Rasmussen and Prys-Jones's studies included painstaking analysis of the way specimens were prepared and the handwriting on tags, together with X-rays of skeletons, to determine which had faked data, and to match specimens with those stolen from other institutions. They ing. "It's the most egregious
IMAGE

UNAVAILABLE FOR COPYRIGHT REASONS
Detailed, accurate tagging of mus eum specimens is crucial for biologists researching bird species. found that Meinertzhagen frequently reported species at locations where they had never been 8 seen before, and documented recent sightings of rare or near-extinct birds.

In one case, he took a specimen of the kingfisher Alcedo hercules that had been found on the island of Hainan off China, and listed it as being from Myanmar. In another, he swiped a forest owlet (Heteroglaux blewitti) skin from the British Museum and retagged it as his own

\title{
Free mice herald launch of Asia-Pacific network
}

\section{SYDNEY}

Developmental biologists in Asia-Pacific countries have come up with an intriguing incentive to boost research in the region giving away transgenic mice for free.

The service is part of a research network launched in Sydney last week at a meeting of the International Society of Developmental Biologists (ISDB), which aims to encourage collaboration between labs in the region. To kick things off, the RIKEN Center for Developmental Biology (CDB) in Kobe, Japan, will make transgenic mice to order for scientists in the region, free of charge.
Studies using transgenic mice can reveal the functions of genes, particularly during embryonic development. But the mice are expensive to create, so providing them for free should help researchers in developing countries in the region, says Shinichi Aizawa of the CDB, who heads the service.

"The service will be very useful, especially for those scientists who don't have their own facilities to generate knockout mice," agrees Kathy Cheah, a developmental biologist at the University of Hong Kong.

But there are strings attached. The CDB will own the mice, and requires co- authorship on the first publication generated from the use of each mouse. Ownership will be retained to ensure that the mice produced are available to all scientists, says Aizawa. He adds that if the mice are to be used commercially, an agreement will need to be negotiated between the various parties involved.

The mice will be the first stepin bolstering regional ties, says Masatoshi Takeichi, director of the CDB and newly elected president of the ISDB. "Interactions between countries in the region are very weak, and yet geographically we are so close," he says. 


\section{IMAGE}

UNAVAILABLE FOR COPYRIGHT REASONS

discovery. That gave him credit for having found the last of the species in 1914, when it had actually been discovered in India in the 1880 s by another collector. Rasmussen herself has since rediscovered the forest owlet alive in India, while she was investigating Meinertzhagen's role in the fraud.

Rasmussen and Prys-Jones have now corrected as many of the tags as possible, and are soon to publish a long article on the malfea- sance, to serve as a guide for scientists studying the Tring collection. It may also inform the use of other Meinertzhagen specimens, which are housed at the American Museum of Natural History in New York and the World Museum Liverpool, UK. Those collections aren't believed to have such problems, say officials at the museums, but they haven't been thoroughly checked.

RexDalton
The research network, called the Asia-Pacific Developmental Biology Network, includes Japan, China, Taiwan, Singapore, South Korea, India, Australia and New Zealand, but in the future could extend as far as Iran and Hawaii. It is a grass-roots initiative supported by, but independent of, the ISDB. "The aim is for members to share each other's laboratories with no barriers," says K. VijayRaghavan, director of the National Centre for Biological Sciences in Bangalore, India.

Participants will share ideas and information through the Internet, and host institutes will help cover travel and research costs for students and researchers. Members will also take advantage of each other's specialist facilities, including the CDB's transgenic mouse production scheme, India's liver-cellimaging technology and Singapore's zebrafish expertise. "The goal is to create a vibrant intellectual environment in the region," says VijayRaghavan.

The research network was lauded by delegates in Sydney. "Researchers in Asia have lots of links with labs in the West, but not so many within the region. We hope the network will change that," says Cheah.

The CDB will start its mouse service this month with collaborators in India. Researchers should receive the mice within a year of sending the DNA constructs or sequence data needed to make the animals. Carina Dennis 